\title{
Early Predictors for INtubation-SURfactant- Extubation Failure in Preterm Infants with Neonatal Respiratory Distress Syndrome: A Systematic Review
}

\author{
Barbara De Bisschop $^{\text {a }}$ Frank Derriks $^{b}$ Filip Cools $^{a}$ \\ aDepartment of Neonatology, Vrije Universiteit Brussel, University Hospital Brussels, Brussels, Belgium; \\ ${ }^{b}$ Department of Neonatology, Université Libre de Bruxelles, Hôpital Erasme, Brussels, Belgium
}

\section{Keywords}

Surfactant $\cdot$ Nasal continuous positive airway pressure $\cdot$ Risk factors · Extubation failure · Premature neonate

\begin{abstract}
The INtubation-SURfactant-Extubation (INSURE) procedure is a widely-used surfactant administration method to treat preterm infants with respiratory distress syndrome (RDS) but is not always successful. We conducted a systematic review to identify early predictive factors for failure of this procedure. A systematic literature search was performed until July 2018 in MEDLINE, EMBASE, and the Cochrane Central Register of Controlled Trials. Original studies comparing INSURE success with INSURE failure in preterm infants with RDS were included. A predefined data extraction form was used to retrieve data from articles, and methodological quality was assessed using the SIGN checklists. Fifteen studies out of 690 identified records met inclusion criteria. Methodological quality varied, only 8 studies performed multivariate analysis. We identified 20 different risk factors in total. Evidence for birth weight (BW) as a predictor for INSURE failure was inconsistent, but there was a significant association between decreasing gestational age (GA) and failure risk. RDS severity was assessed in multiple ways, using arterial blood gas values, imaging, and scoring systems. In conclusion, extremely
\end{abstract}

low BW, low GA, and severe RDS appear to be risk factors for INSURE failure. However, evidence is inconsistent due to important methodological heterogeneity. Therefore, clinical applicability of these results is limited and implies the need for future large cohort studies on this subject.

C 2019 S. Karger AG, Basel

\section{Introduction}

Neonatal respiratory distress syndrome (RDS) is caused by lung immaturity and surfactant deficiency in preterm newborns and is an important cause of morbidity and mortality. European guidelines on the management of $\mathrm{RDS}$ recommend initiation of nasal continuous positive airway pressure from birth combined with early selective surfactant administration [1-5]. Methods have been developed to administer surfactant while avoiding intubation and mechanical ventilation (MV) as much as possible. One of those methods is the INtubation-SURfactant-Extubation (INSURE) technique, where infants are intubated and surfactant is administered during a very brief period of MV, after which the infant is extubated again and noninvasive respiratory support is continued $[1,6,7]$.

However, this procedure is not always successful. Some infants cannot be extubated after the procedure,

\section{KARGER}

(c) 2019 S. Karger AG, Basel 
while others need to be reintubated in the following hours or days due to hypoxia or hypercapnia [7]. Often, intubation under those circumstances is more urgent and less well tolerated. This could lead to fluctuations in blood pressure, which has been associated with an increased risk of intracranial hemorrhage [8].

For clinicians, it would be helpful to be able to differentiate in the first hours of life those infants who have a good chance of succeeding the INSURE procedure from those who have a high risk of failing it and, therefore, should preferably be intubated electively for surfactant administration and continued MV.

The aim of this systematic review was to identify early predictive factors for failure of the INSURE procedure in preterm infants with RDS and to present an overview of current existing evidence.

\section{Materials and Methods}

\section{Registration}

The methods for this review were specified in advance and have been published in a protocol at PROSPERO [9], registration number CRD42015025138.

\section{Eligibility Criteria}

Studies were included if they (1) included preterm infants $(<37$ weeks' gestation) with RDS; (2) that received surfactant using the INSURE procedure (INtubation, SURfactant administration, brief MV and planned Extubation within a predefined timeframe); and (3) reported on predictive factors for INSURE failure or success. There was no selected time period or language restriction. Studies that were only reported in abstract form were excluded.

\section{Information Sources and Search}

Three structured electronic search strategies, developed by an experienced reviewer (F.C.), were used, and a literature search was conducted through 3 medical databases (B.D.B., F.D.): MEDLINE, EMBASE, and the Cochrane Central Register of Controlled Trials. The final search was run on July 19, 2018. Reference lists of the included studies were checked to identify additional studies. We contacted several authors to obtain missing information.

\section{Study Selection}

After deleting duplicates, eligibility assessment was performed independently by 2 reviewers (B.D.B., F.D.). Title and abstract of all identified studies were screened for relevance. The remaining records were screened for report eligibility criteria and finally inclusion criteria. Disagreements were resolved by consensus, or the third author was consulted for final decision (F.C.).

\section{Data Collection Process}

A data extraction form was developed in advance and pilot-tested on 3 studies. Following information was collected: (1) general information, (2) study characteristics, (3) maternal, (4) neonatal, (5) intervention (including the definition of the INSURE procedure), and (6) outcome characteristics (including the definition of INSURE failure). Data extraction was performed independently by 2 reviewers (B.D.B., F.D.), and discrepancies were resolved by consensus. Multiple publications were collated and assessed as one study.

\section{Study Quality Assessment}

Methodological quality of the included studies was assessed independently by 2 authors (B.D.B., F.C.) using the SIGN methodology checklist for cohort studies and randomized controlled trials [10]. Following items were evaluated: presence of a clearly focused question; selection, attrition, and detection bias; possibility of confounding and statistical analysis. Overall study quality was discussed among the reviewers and expressed as high, acceptable, or low according to consensus.

\section{Data Synthesis}

Our results are presented in accordance with the PRISMA guidelines $[11,12]$. Risk factors that were statistically significant, in any study, in either univariate analysis, analysis of variance, or multivariate analysis (final analysis, $p$ value $<0.05$ ), are presented in summary tables. Continuous outcomes are presented as means (and SD) or medians (and range). Dichotomous outcomes are expressed as ORs or relative risks with 95\% CI.

As stated in our review protocol, we intended to statistically combine the results of the individual studies into a meta-analysis where possible. However, due to important study heterogeneity and variability of data in the reported results, we were unable to statistically combine the results of the included studies.

\section{Results}

\section{Study Selection}

The search retrieved 1,076 records and 29 additional records were identified through hand-searching of reference lists and contacting authors. After adjusting for duplicates, title and abstract of 690 records were screened. Because of irrelevance to the review question, 548 records were excluded, while another 85 records were discarded because they met one or more exclusion criteria. Even though we sought to include all eligible articles without language restriction, we had to exclude one additional record because it was written in Persian, and we were unable to translate it [13]. The full-text of 56 articles was assessed for eligibility. Finally, fifteen original studies met inclusion criteria [14-28] (Fig. 1).

\section{Study Characteristics}

The main characteristics and in- and exclusion criteria are summarized in Table 1 . The included studies involved a total of 1,674 patients with a median sample size of 75 (range 21-322). Inclusion criteria varied. The INSURE procedure was not only generally well described but also differed between studies. The (primary) outcome as- 
Fig. 1. Flow diagram of the study selection process. CENTRAL, Cochrane Central Register of Controlled Trials.

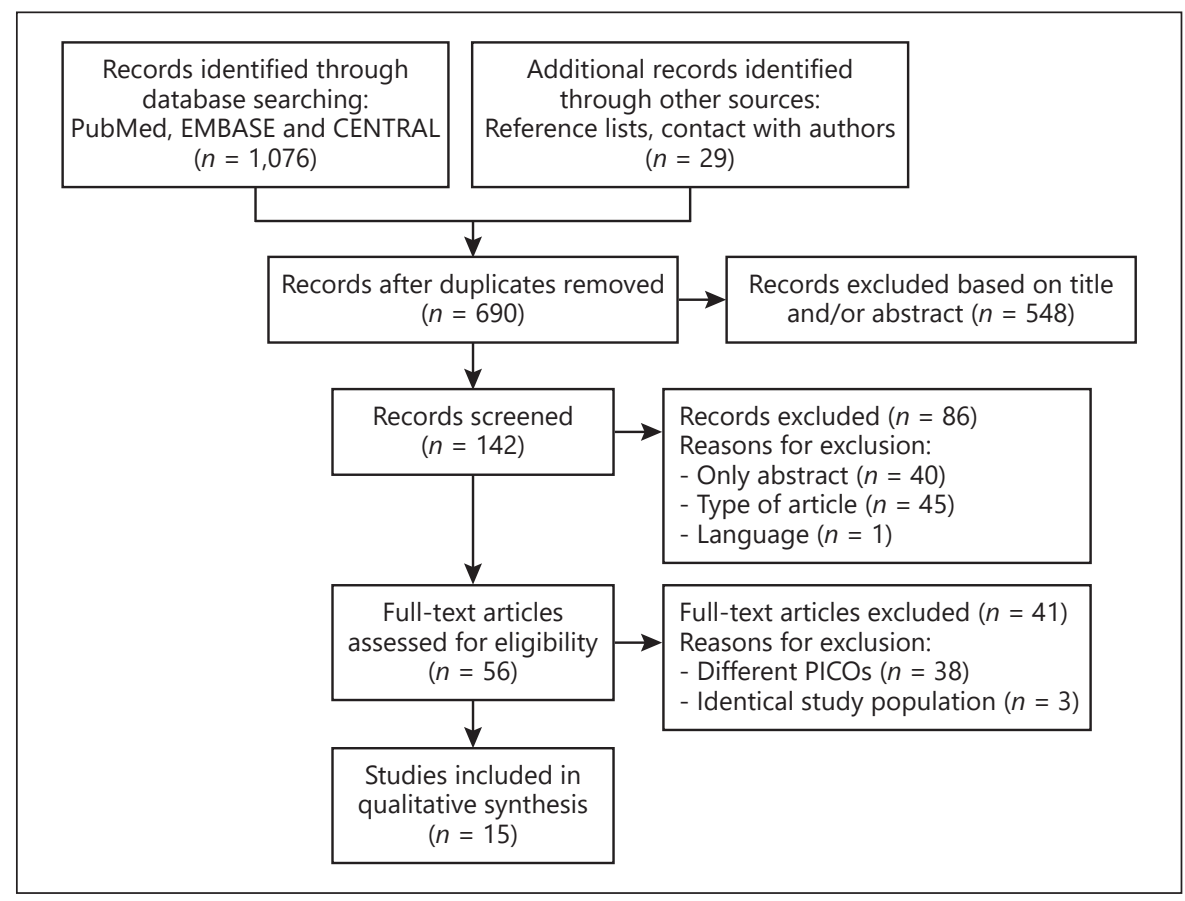

sessed was INSURE failure, for which the definition in the included trials is presented in Table 2. The median INSURE failure rate was 33.3\% (range 9.3-52.4).

\section{Study Quality Assessment}

The methodological quality of the included studies is presented in Figure 2. None of the studies referred to existing evidence supporting their definition of INSURE failure; instead, a new definition was proposed in each study. Eight studies adjusted for possible confounding in a multivariate analysis, although the statistical methods were not always clearly described. After detailed quality assessment, we categorized 4 studies as being high-quality studies $[16,17,19,26], 7$ studies as being of acceptable quality $[14,18,20-23,28]$, and 4 studies as having a low methodological quality $[15,24,25,27]$.

\section{Predictive Factors of INSURE Failure}

Birth Weight

All studies evaluated BW as a potential predictive factor (online suppl. Appendix 1; for all online suppl. material, see www.karger.com/doi/10.1159/000501654). In 10 studies, a significantly lower BW was found in infants who failed INSURE $[14,15,17,18,20-24,27]$, whereas in one study the association was in the opposite direction [26]. Only 7 studies investigated the predictive value of BW in a multivariate analysis (total of 739 patients) [16-19, 21, $23,26]$ of which 2 found a significant association. Dani et al. [19] reported that having a $\mathrm{BW}<750 \mathrm{~g}$ increased the risk of INSURE failure significantly with an adjusted relative risk of 2.77 (95\% CI 1.26-6.14). In the study by Li et al. [21], an adjusted OR (aOR) for INSURE failure of 22 was found for a $\mathrm{BW}<1,150 \mathrm{~g}$, but the $\mathrm{CI}$ around that estimate was extremely wide (95\% CI 2.124-232.90).

\section{Gestational Age}

All but one study investigated gestational age (GA) as a possible predictor for INSURE failure [15] (online suppl. Appendix 2). In 7 out of the 15 studies, a significantly lower GA was found in infants who failed INSURE as compared to those who succeeded $[14,18,20,22,24,27,28]$. In multivariate analysis (3 studies, including 514 patients) $[16,18$, 26], a significant association was found in only 2 studies. In Brix's study, each 2-week decrease in GA increased the odds of failing INSURE with a factor 1.8 (95\% CI 1.2-2.8) [16]. In Danaei's study, having a GA of 30 weeks or more, as compared to a GA of $<30$ weeks, decreased the risk of INSURE failure with an aOR of 0.78 (95\% CI 0.67-0.91) [18].

\section{Severity of RDS}

Nine factors corresponding with the severity of RDS were identified (online suppl. Appendix 3).

Arterial Blood Gas Analysis: Seven studies evaluated partial carbon dioxide pressure $\left(\mathrm{pCO}_{2}\right)$ prior to INSURE procedure $[14,16,17,19-21,27]$. In 4 of those studies, a significantly higher $\mathrm{pCO}_{2}$ prior to INSURE was found 


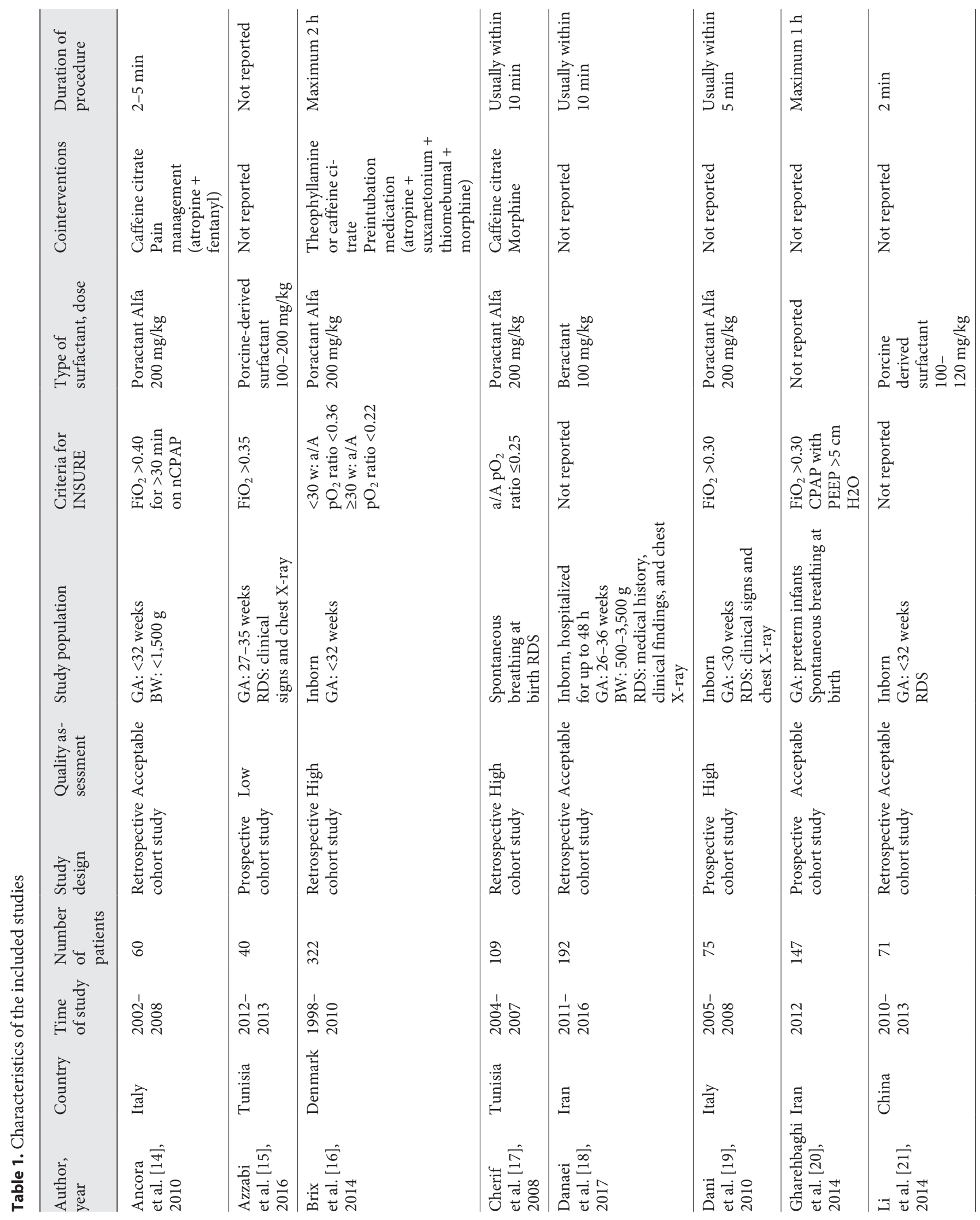




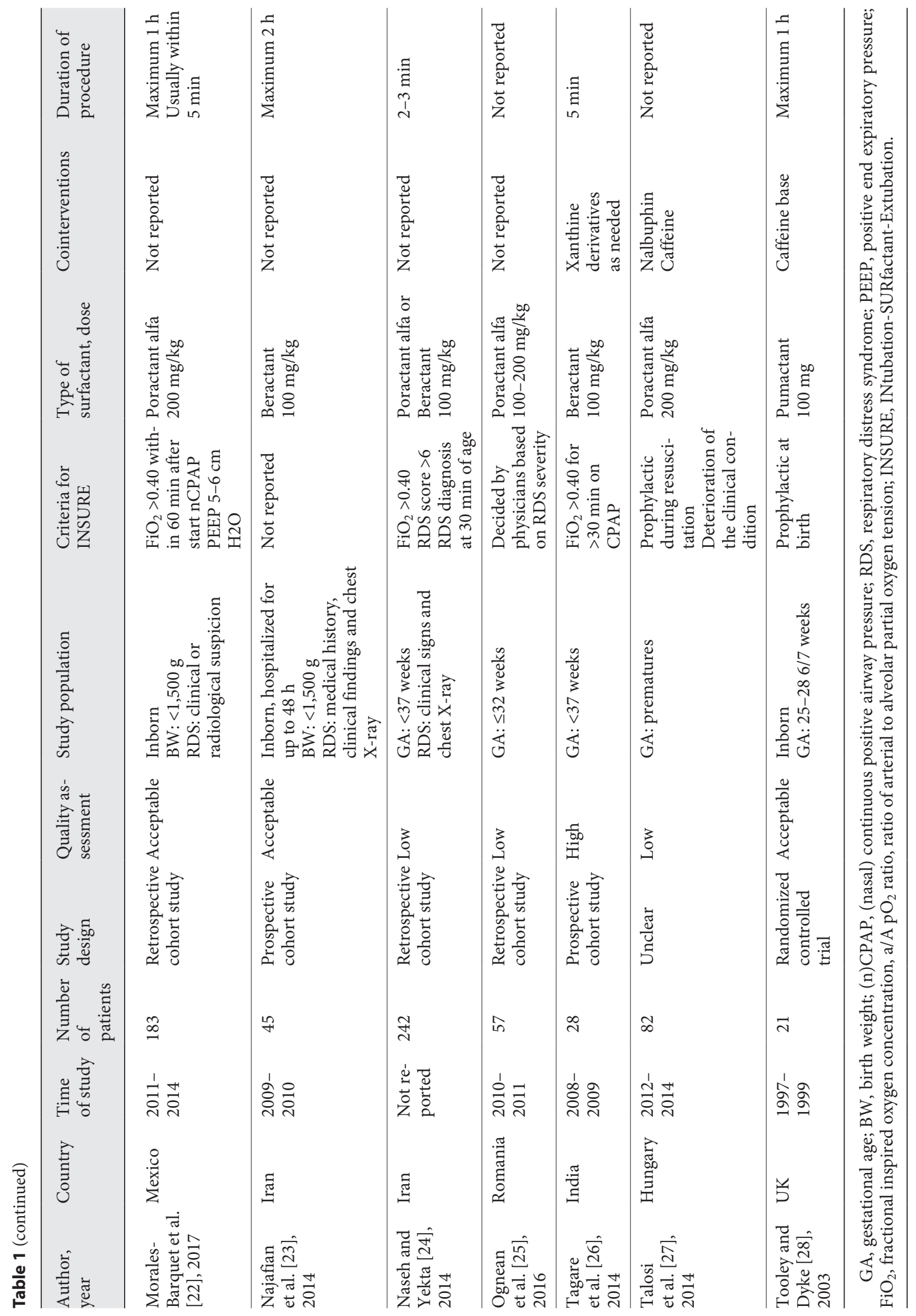


Table 2. Outcome definitions in the included studies

\begin{tabular}{|c|c|c|c|c|}
\hline $\begin{array}{l}\text { Author, } \\
\text { year }\end{array}$ & $\begin{array}{l}\text { INSURE } \\
\text { failure } \\
\text { rate, } \%\end{array}$ & $\begin{array}{l}\text { Criteria for } \\
\text { INSURE failure }\end{array}$ & Criteria for mechanical ventilation & Notes \\
\hline $\begin{array}{l}\text { Azzabi } \\
\text { et al. [15], } \\
2016\end{array}$ & 32.5 & $\begin{array}{l}\text { Need for MV } \\
\text { within } 72 \mathrm{~h}\end{array}$ & $\begin{array}{l}\mathrm{FiO} 2:>0.45 \\
\text { Progressive respiratory failure }\end{array}$ & \\
\hline $\begin{array}{l}\text { Brix } \\
\text { et al. [16], } \\
2014\end{array}$ & 24.8 & $\begin{array}{l}\text { Need for MV } \\
\text { within } 72 \mathrm{~h}\end{array}$ & $\begin{array}{l}\text { Acute respiratory insufficiency } \\
\text { ABG: } \mathrm{pH}<7.20 \text {, a/A pO2 ratio }<0.15\end{array}$ & $\begin{array}{l}\text { Neonates mechanically } \\
\text { ventilated during } \\
\text { surfactant administration } \\
(>2 \mathrm{~h}) \text { : Short MV }(\leq 24 \mathrm{~h}) \\
\text { Long MV }(>24 \mathrm{~h})\end{array}$ \\
\hline
\end{tabular}

\begin{tabular}{lll}
\hline Cherif & 32.1 & $\begin{array}{l}\text { Need for MV } \\
\text { et al. [17], }\end{array}$ \\
2008 & & within $72 \mathrm{~h}$
\end{tabular}

FiO2: $>0.60$
ABG: $\mathrm{pH}<7.20, \mathrm{pCO}_{2}>65 \mathrm{~mm} \mathrm{Hg}, \mathrm{a} / \mathrm{A}$ pO2

ratio $<0.15, \mathrm{BE}>10 \mathrm{mmol}$ not responsive to

treatment Apnea: $>3$ episodes in $3 \mathrm{~h}$,

unresponsive to stimulation and

caffeine treatment

\begin{tabular}{|c|c|c|c|}
\hline $\begin{array}{l}\text { Danaei } \\
\text { et al, [18], } \\
2017\end{array}$ & 41.1 & $\begin{array}{l}\text { Need for MV } \\
\text { within } 24 \mathrm{~h}\end{array}$ & $\begin{array}{l}\text { FiO: } 2>0.40 \\
\mathrm{ABG}: \mathrm{pH}<7.20, \mathrm{pO} 2<50 \mathrm{~mm} \mathrm{Hg} \text {, } \\
\mathrm{pCO}_{2}>60 \mathrm{~mm} \mathrm{Hg} \\
\text { Apnea: recurrent } \\
\text { Target saturation: }>85 \%\end{array}$ \\
\hline $\begin{array}{l}\text { Dani } \\
\text { et al. [19], } \\
2010\end{array}$ & 9.3 & $\begin{array}{l}\text { Need for MV } \\
\text { within } 72 \mathrm{~h}\end{array}$ & $\begin{array}{l}\mathrm{FiO} 2>0.50 \\
\mathrm{ABG}: \mathrm{pH}<7.20, \mathrm{pO} 2<50 \mathrm{~mm} \mathrm{Hg}, \\
\mathrm{pCO}_{2}>65 \mathrm{~mm} \mathrm{Hg} \\
\text { Apnea: Frequent episodes requiring repeated } \\
\text { stimulation or bag-and-mask ventilation } \\
\text { Target saturation: } 85-95 \% \text { nCPAP pressure: } 5-6 \\
\mathrm{~cm} \mathrm{H} \mathrm{H}_{2} \mathrm{O}\end{array}$ \\
\hline $\begin{array}{l}\text { Gharehbaghi } \\
\text { et al. [20], } 2014\end{array}$ & 30.6 & $\begin{array}{l}\text { Need for MV } \\
\text { within } 72 \mathrm{~h} \\
\text { No extubation } \\
\text { after } 1 \mathrm{~h}\end{array}$ & $\begin{array}{l}\text { FiO2: }>0.50 \\
\text { ABG: } \mathrm{pH}<7.20, \mathrm{pO} 2<50 \mathrm{~mm} \mathrm{Hg} \text {, } \\
\text { pCO }>65 \mathrm{~mm} \mathrm{Hg} \\
\text { Apnea: }>4 \text { episodes per } \mathrm{h} \\
\text { Target saturation: } 88-92 \%\end{array}$ \\
\hline $\begin{array}{l}\text { Morales-Barquet } \\
\text { et al. [22], } 2017\end{array}$ & 38.8 & $\begin{array}{l}\text { Need for MV } \\
\text { within } 72 \mathrm{~h}\end{array}$ & $\begin{array}{l}\text { FiO2: }>0.60 \\
\text { ABG: } \mathrm{pH}<7.20, \mathrm{pO} 2<0.35, \mathrm{pCO}_{2}>65 \mathrm{~mm} \mathrm{Hg} \\
\text { Apnea: }>6 \text { episodes in } 6-12 \mathrm{~h}, 2 \text { requiring PPV in } \\
12 \mathrm{~h} \\
\text { Target saturation: }>88 \% \\
\text { nCPAP pressure: } 5-6 \mathrm{cmH}_{2} \mathrm{O} \\
\text { Severe RDS (Silverman-Andersen classification }>5 \\
\text { points) Need for second dose of surfactant }\end{array}$ \\
\hline
\end{tabular}


Table 2 (continued)

\begin{tabular}{|c|c|c|c|c|}
\hline $\begin{array}{l}\text { Author, } \\
\text { year }\end{array}$ & $\begin{array}{l}\text { INSURE } \\
\text { failure } \\
\text { rate, } \%\end{array}$ & $\begin{array}{l}\text { Criteria for } \\
\text { INSURE failure }\end{array}$ & Criteria for mechanical ventilation & Notes \\
\hline $\begin{array}{l}\text { Ognean et al. } \\
{[25], 2016}\end{array}$ & $45.6 \%$ & $\begin{array}{l}\text { Need for MV } \\
\text { within } 72 \mathrm{~h}\end{array}$ & Not reported & \\
\hline $\begin{array}{l}\text { Talosi et al. } \\
\text { [27], } 2014\end{array}$ & $25.6 \%$ & $\begin{array}{l}\text { Need for MV } \\
\text { within } 7 \text { days } \\
\text { Absence of } \\
\text { respiratory drive }\end{array}$ & $\begin{array}{l}\text { Deterioration of clinical condition } \\
\text { (grunting, chest retractions, cyanosis) }\end{array}$ & $\begin{array}{l}67 \% \text { intubated at birth (no } \\
\text { clear indications reported) }\end{array}$ \\
\hline $\begin{array}{l}\text { Tooley et al. } \\
{[28], 2003}\end{array}$ & $52.4 \%$ & $\begin{array}{l}\text { Need for MV } \\
\text { within } 48 \mathrm{~h} \\
\text { (= unsuccessful } \\
\text { extubation) }\end{array}$ & $\begin{array}{l}\text { FiO2: }>0.70 \\
\text { ABG: } \mathrm{pH}<7.20 \text {, pO2 }<45 \mathrm{~mm} \mathrm{Hg} \\
\text { Significant apnea } \\
\text { nCPAP pressure: } \max 9 \mathrm{~cm} \mathrm{H}_{2} \mathrm{O}\end{array}$ & $\begin{array}{l}\text { Separate group for } \\
\text { neonates that were not } \\
\text { extubated }\end{array}$ \\
\hline
\end{tabular}

$\mathrm{MV}$, mechanical ventilation; CPAP, continuous positive airway pressure; PEEP, positive end expiratory pressure; ABG, arterial blood gas; PPV, positive pressure ventilation; BE, base excess; RDS, respiratory distress syndrome; INSURE, INtubation-SURfactant-Extubation; nCPAP, nasal continuous positive airway pressure.

in infants who failed as compared to infants who succeeded INSURE [17, 19-21]. Three studies performed a multivariate analysis (including 502 patients) with $\mathrm{pCO}_{2}$ prior to INSURE procedure as covariate $[16,17,21]$. In the study by Cherif et al. [17], a $\mathrm{pCO}_{2}$ of $>50 \mathrm{~mm} \mathrm{Hg}$ increased the odds of failure significantly with a factor 1.82 (95\% CI 1.76-90.56), and in the study by Li et al. [21], the aOR for a $\mathrm{pCO}_{2}$ value above $54 \mathrm{~mm} \mathrm{Hg}$ prior to INSURE to fail the procedure was 9.63 (95\% CI 1.9644.74).

Six studies reported on partial oxygen pressure $\left(\mathrm{pO}_{2}\right)$ before INSURE procedure [16, 17, 19-21, 27]. In only 1 study, a significantly lower $\mathrm{pO}_{2}$ prior to INSURE was found in infants who failed the procedure [21]. The one study that used $\mathrm{pO}_{2}$ prior to INSURE as a covariate in a multivariate analysis, did not find a significant association [16].

Early Predictors for INSURE Failure in Preterm Neonates
Six studies evaluated fractional inspired oxygen concentration $\left(\mathrm{FiO}_{2}\right)$ before INSURE procedure [14-16, 19, $20,25]$, which was significantly higher in infants who failed as compared to infants who succeeded INSURE in 3 studies $[15,19,20]$. In multivariate analysis (362 patients), a significant association was found in only one low-quality study [15].

Five studies investigated arterial-to-alveolar partial oxygen pressure ratio prior to INSURE procedure as an early predictor of INSURE failure [16, 17, 19, 21, 26]. In 3 of those studies, the a/A-ratio was significantly lower in infants who failed INSURE $[17,19,21]$. Multivariate analyses (4 studies including 534 patients) are inconsistent, both in the cutoff points that were used in the different studies (varying between 0.44 and 0.18 ) as well as in their results $[16,17,19,26]$. The partial arterial oxygen tension $\left(\mathrm{paO}_{2}\right)$ to $\mathrm{FiO}_{2}$ ratio was evaluated in 2 studies, 


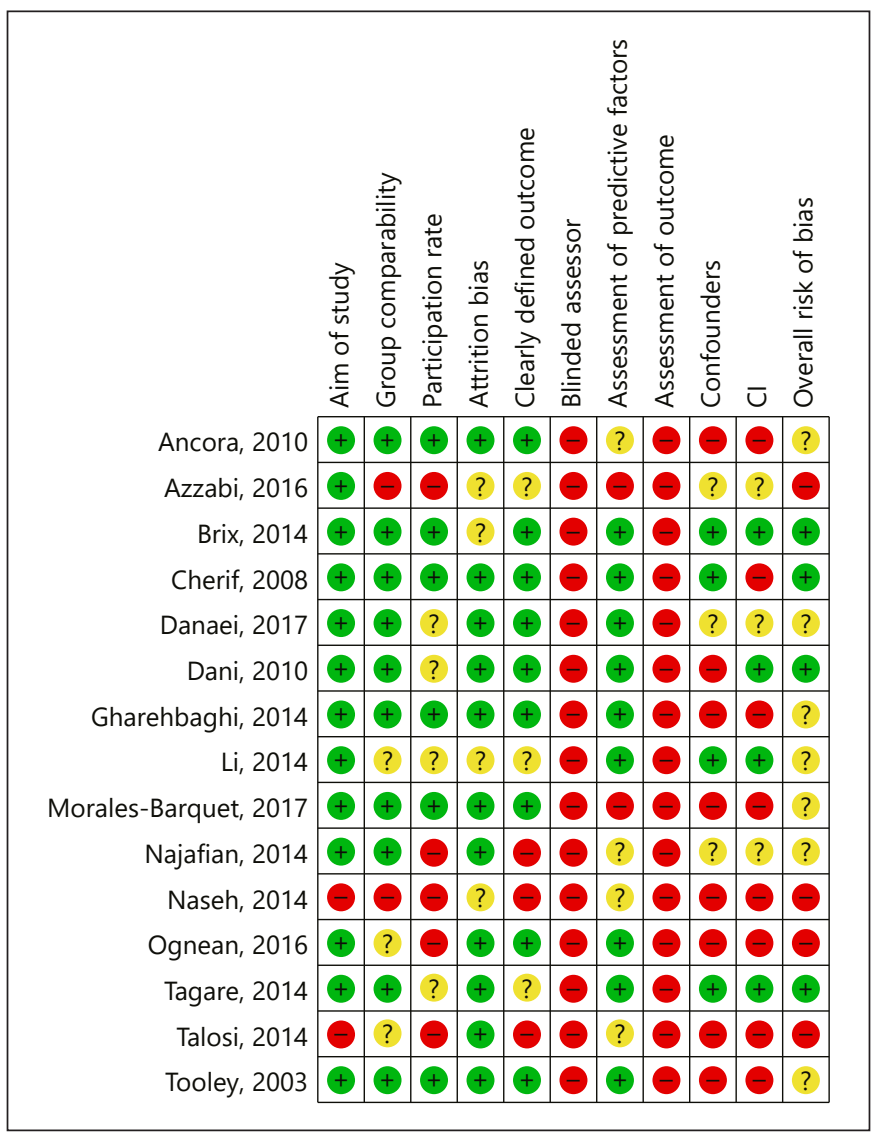

Fig. 2. Quality assessment of the included studies.

which both found a statistically significant association with treatment failure in multivariate analyses $[19,21]$. In Dani's study, a $\mathrm{paO}_{2} / \mathrm{FiO}_{2}<218$ increased the odds of failure with a factor 1.88 (95\% CI 1.26-2.80), whereas in Li's study, the aOR of a $\mathrm{paO}_{2} / \mathrm{FiO}_{2}<195$ for INSURE failure was 6.57 (95\% CI 1.02-42.00). Oxygenation index was evaluated in only 1 study, and the analysis was not adjusted for possible confounding [28].

Clinical and Radiological Diagnosis: Four studies reported on a clinical RDS severity score, using either the Silverman-Andersen score $[22,26]$ or an unreferenced scoring system $[18,20]$. In 3 of those studies, the RDS score was significantly associated with INSURE failure in unadjusted analyses $[18,20,22]$. Only one study confirmed this association after adjusting for confounders and reported an increase in failure with an OR of 6.31 (95\% CI 2.07-19.9) [18]. However, the exact definition of the variable as it was introduced in the multivariate model was unclear.

The severity of RDS on chest X-ray was evaluated in 3 studies $[15,17,20]$. All studies used the same classifica- tion system of mild, moderate, or severe radiological RDS as described by Kero and Mäkinen [29]. A statistically significant association was found between the presence of severe radiological RDS and the risk of INSURE failure in 2 studies [15, 17].

\section{Other Early Predictive Factors}

Ten other factors were evaluated as potential predictive factors for INSURE failure. A summary of these data is provided in Table 3. Noteworthy, a serum hemoglobin level $<14 \mathrm{~g} / \mathrm{dL}$ prior to INSURE was found to be significantly associated with failure in 1 out of 2 studies $[16,17]$. Furthermore, Ognean et al. [25] reported a significant association with pregnancy complications. In the other included studies, different types of pregnancy complications (such as hypertension, preeclampsia, and diabetes) were evaluated as predictive factors, but were never found to be significantly associated with INSURE failure [16$23,25]$.

\section{Discussion}

\section{Summary of Evidence}

This is the first systematic review to present an overview of early clinical factors predicting failure of the INSURE procedure performed in preterms with RDS. We identified 21 possible predictors in 15 original studies. Birth weight (BW), GA, and RDS severity were the most frequently assessed factors.

Although in most studies, average BW was lower in infants who failed INSURE, the evidence for BW as an independent predictor for INSURE failure was inconsistent. Multivariate analysis in Brix's study even found a potentially protective effect of an extremely low BW $(<1,000 \mathrm{~g})$, although not statistically significant [16]. There is no obvious explanation for this unexpected finding. Study design differed concerning inclusion criteria, indication for INSURE, and use of sedative medication. In addition, several study groups used a different cutoff value for the ELBW group, which complicates direct comparison of these results. Although based on only 5 studies, being small for GA does not appear to be an independent risk factor of INSURE failure. Thus, although there is some suggestion that an extremely low BW might be associated with an increased risk of INSURE failure, the evidence is weakened by inconsistency and does not allow determining a safe cutoff value or making clear recommendations for clinical practice.
40

Neonatology 2020;117:33-45 DOI: $10.1159 / 000501654$
De Bisschop/Derriks/Cools 
Table 3. Summary of the results on other possible early predictive factors for INSURE failure

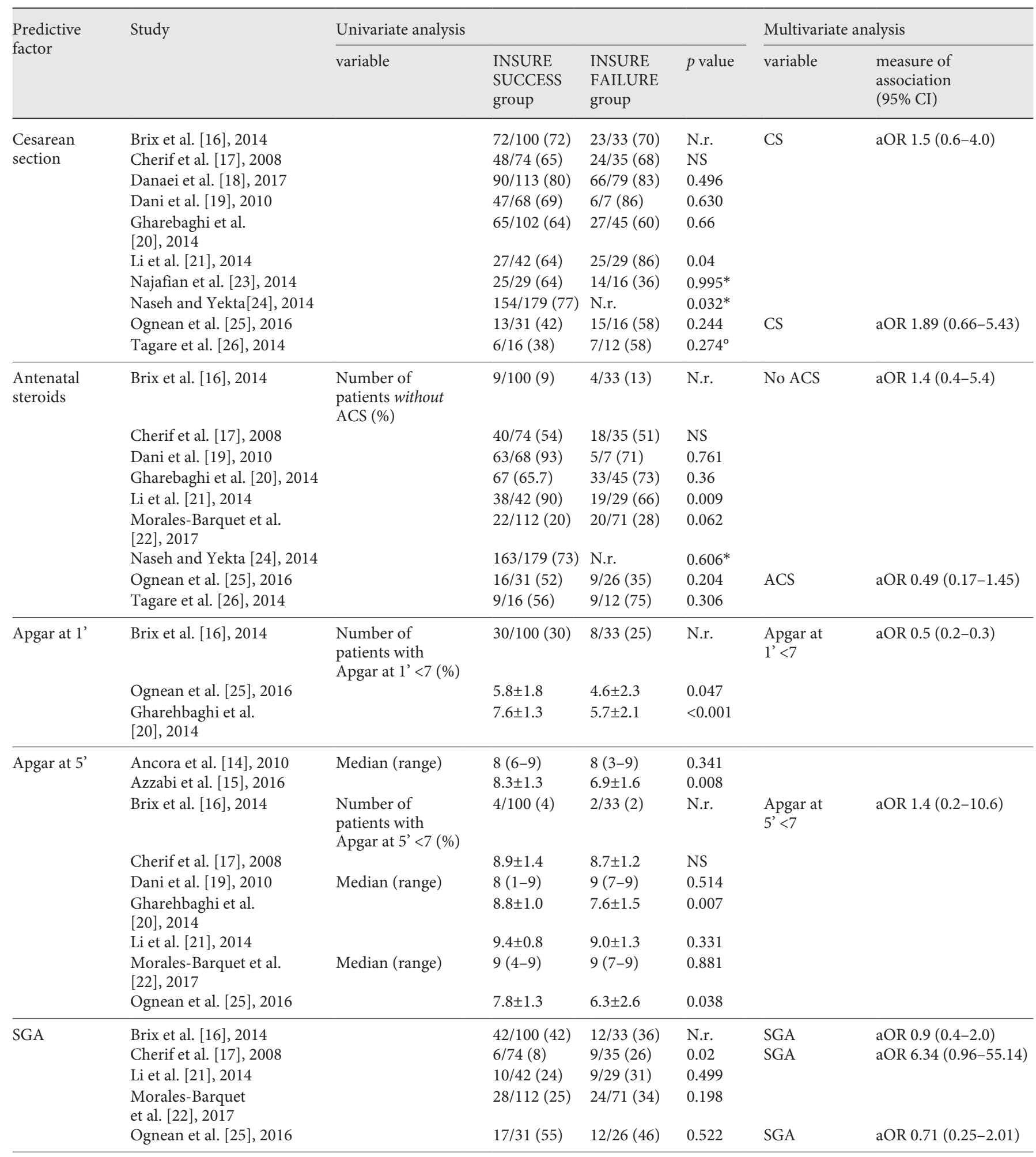


Table 3 (continued)

\begin{tabular}{|c|c|c|c|c|c|c|c|}
\hline \multirow{2}{*}{$\begin{array}{l}\text { Predictive } \\
\text { factor }\end{array}$} & \multirow[t]{2}{*}{ Study } & \multicolumn{4}{|l|}{ Univariate analysis } & \multicolumn{2}{|c|}{ Multivariate analysis } \\
\hline & & variable & $\begin{array}{l}\text { INSURE } \\
\text { SUCCESS } \\
\text { group }\end{array}$ & $\begin{array}{l}\text { INSURE } \\
\text { FAILURE } \\
\text { group }\end{array}$ & $p$ value & variable & $\begin{array}{l}\text { measure of } \\
\text { association } \\
(95 \% \mathrm{CI})\end{array}$ \\
\hline \multirow[t]{3}{*}{ Hemoglobin } & Brix et al. [16], 2014 & $\begin{array}{l}\text { Number of } \\
\text { patients with } \\
\mathrm{Hb}<8.5 \mathrm{mmol} / \mathrm{L}(\%)\end{array}$ & $2 / 100(3)$ & $5 / 33(21)$ & N.r. & $\begin{array}{l}\mathrm{Hb}<8.5 \\
\mathrm{mmol} / \mathrm{L}\end{array}$ & aOR $5.1(1.0-25.8)$ \\
\hline & Cherif et al. [17], 2008 & $\begin{array}{l}\text { Number of } \\
\text { patients with } \\
\mathrm{Hb}<14 \mathrm{~g} / \mathrm{dL}(\%)\end{array}$ & $8 / 74(11)$ & $10 / 35(28)$ & 0.01 & $\begin{array}{l}\mathrm{Hb}<14 \mathrm{~g} / \\
\mathrm{L}^{\#}\end{array}$ & aOR $8.33(0.99-40.23)$ \\
\hline & & $\begin{array}{l}\text { Serum Hb } \\
\text { level, g/dL }\end{array}$ & $16.3 \pm 2.2$ & $15.8 \pm 1.7$ & NS & & \\
\hline Procalcitonin & Talosi et al. [27], 2014 & $\mathrm{ng} / \mathrm{mL}$ & $18.9 \pm 19.3$ & $45.3 \pm 63.0$ & 0.0085 & & \\
\hline $\begin{array}{l}\text { Complicated } \\
\text { pregnancy }\end{array}$ & Ognean et al. [25], 2016 & & 6/31 (19) & $13 / 26(50)$ & 0.014 & $\begin{array}{l}\text { Complicated } \\
\text { pregnancy }\end{array}$ & $\mathrm{aOR} 4.17(1.28-13.52)$ \\
\hline \multirow[t]{6}{*}{ Pneumothorax } & Brix et al. [16], 2014 & & $2 / 100(2)$ & $8 / 33(25)$ & $<0.05$ & & \\
\hline & Cherif et al. [17], 2008 & & $0 / 74(0)$ & $2 / 35(6)$ & NS & & \\
\hline & Danaei et al. [18], 2017 & & $3 / 113(2)$ & $25 / 79(31)$ & $<0.001$ & Pneumothorax & aOR $1.32(0.5-4.6)$ \\
\hline & Dani et al. [19], 2010 & & $0 / 68(0)$ & $2 / 7(28)$ & 0.001 & & \\
\hline & Li et al. [21], 2014 & & $0 / 42(0)$ & $1 / 29(3)$ & 0.851 & & \\
\hline & Najafian et al. [23], 2014 & & $0 / 29(0)$ & $2 / 16(12)$ & $0.999^{*}$ & & \\
\hline \multirow[t]{9}{*}{ Infection } & Cherif et al. [17], 2008 & Early-onset infection & $10 / 74(13)$ & $5 / 35(14)$ & NS & & \\
\hline & & Nosocomial sepsis & $18 / 74(24)$ & $10 / 35(28)$ & NS & & \\
\hline & Danaei et al. [18], 2017 & Sepsis & $18 / 113(16)$ & $20 / 79(25)$ & 0.108 & & \\
\hline & Dani et al. [19], 2010 & Chorioamnionitis & $3 / 68(4)$ & $0 / 7(0)$ & 0.656 & & \\
\hline & & Sepsis & $16 / 68(24)$ & $5 / 7(71)$ & 0.025 & & \\
\hline & $\begin{array}{l}\text { Morales-Barquet et al. } \\
{[22], 2017}\end{array}$ & Sepsis (\%) & $74 / 112(66)$ & $50 / 71(70)$ & 0.539 & Sepsis & aOR $1.13(0.75-1.69)$ \\
\hline & & Chorioamnionitis & $7 / 112(7)$ & $11 / 71(17)$ & 0.062 & & \\
\hline & Najafian et al. [23], 2014 & Sepsis & $6 / 29(21)$ & $4 / 16(25)$ & $0.641^{*}$ & & \\
\hline & Ognean et al. [25], 2016 & Chorioamnionitis & $1 / 31(3)$ & $0 / 26(0)$ & 0.544 & & \\
\hline
\end{tabular}

* ANOVA (analysis of variance); ${ }^{\circ} p$ value for normal vaginal delivery; ${ }^{*}$ conversion factor for hemoglobin for $\mathrm{mmol} / \mathrm{L}$ to $\mathrm{g} / \mathrm{dL}=1.6114(8.5 \mathrm{mmol} / \mathrm{L}$ $=13.70 \mathrm{~g} / \mathrm{dL}$ ). Values in univariate analyses represent either mean \pm SD or number of patients (\%), unless otherwise noted. N.r., not reported; CS, caesarean section; aOR, adjusted OR; NS, not significant; ACS, antenatal corticosteroids; SGA, small for gestational age; Hb, hemoglobin. Typography.

In many of the included studies, the average GA was significantly lower in infants who failed INSURE, suggesting that the degree of immaturity is a contributing factor. According to Brix's study, in which adjustments were made for possible confounding, each 2-week decrease in GA increases the odds of INSURE failure with a factor 1.8 [16]. Particularly infants with a GA of $<26$ weeks had a much higher risk of INSURE failure with an adjusted OR of almost 10 as compared to infants with a GA of 30-31 weeks. These data suggest that we probably should be more cautious when considering an INSURE in extremely low GA infants.

Assessing RDS severity in the first hours after birth could be another potentially useful way to select infants for either INSURE or intubation and continued MV. The question is which parameter to use and at which cutoff point. The use of $\mathrm{pCO}_{2}$ is supported by 2 studies showing that hypercapnia $\left(\mathrm{pCO}_{2}>50-55 \mathrm{~mm} \mathrm{Hg}\right)$ prior to INSURE is indicative of a higher risk of failure. Among the various indices of oxygenation that have been investigated, the arterial-to-alveolar oxygen tension ratio (a/A-ratio) has been studied the most. However, results are difficult to apply in clinical practice because of inconsistency between studies both regarding the cutoff value that was used (between 0.18 and 0.44), as well as in their findings. In addition, calculating an a/A-ratio is rather complicated requiring both $\mathrm{pO}_{2}$ and $\mathrm{pCO}_{2}$. The $\mathrm{paO}_{2} / \mathrm{FiO}_{2-}$ ratio, which is easier to calculate, was also found to be 
associated with the risk of INSURE failure, although the applicability in daily practice is again questionable. Applying the cutoff values that were used in the 2 studies (i.e., $<195$ and $<218$ ) would mean that, for example, an infant with a $\mathrm{pO}_{2}$ of $70 \mathrm{~mm} \mathrm{Hg}$ would be at increased risk of failing INSURE if the $\mathrm{FiO}_{2}$ prior to INSURE exceeds $0.32-0.36$, which is only slightly above the level of indication for surfactant therapy.

The remaining RDS severity indices were analyzed using heterogeneous methodologies. Other composite indices, which are mostly used to quantify the severity of (chronic) respiratory failure, have also been considered to predict respiratory failure in early stages of RDS and even to guide medical interventions [30-33]. Among them are the oxygenation index (OI), A-a $\mathrm{DO}_{2}$ (alveolar-arterial oxygen difference), and $\mathrm{paO}_{2} / \mathrm{FiO}_{2}$. However, they were poorly investigated in general.

Thus, until today, available studies do not support the use of any respiratory index or clinical score for RDS severity to reliably select infants in the first hours of life for either INSURE or intubation and continued MV.

Interestingly, a low serum hemoglobin level was found to be significantly associated with a higher risk of INSURE failure [16, 17]. We could not find a clear underlying mechanism for this result. Brix et al. [16] speculated that this might be related to the insufficient oxygen delivery to the peripheral tissues leading to lactic acidosis and decreasing $\mathrm{pH}$, but he failed to show an association between high lactate or low $\mathrm{pH}$ and INSURE failure. Lactate has not been investigated in any of the other included studies. Differences in $\mathrm{pH}$ before INSURE procedure were addressed in 5 of the included studies, but none of them found a significant association with INSURE failure $[14,16,17,20,27]$. The association with low serum hemoglobin deserves more attention in future research.

Evidently, factors related to the procedure itself also play an important role in the success or failure of the INSURE procedure. One such factor is the type of exogenous surfactant and the dosing regimen that was used. Current guidelines recommend the use of poractant alfa at a dose of $200 \mathrm{mg} / \mathrm{kg}$ [1]. Except for some studies using beractant, most of the included studies used this type of surfactant at a dose of $100-200 \mathrm{mg} / \mathrm{kg}$ (Table 1). Another factor of interest is the use of sedative medication, with the possible side effect of respiratory depression. However, data on sedation were lacking for most of the included studies (Table 1), making it impossible to make any statement on this topic.

European guidelines on RDS treatment now state that minimally invasive surfactant treatment (MIST) [34] or

Early Predictors for INSURE Failure in Preterm Neonates less invasive surfactant administration (LISA) [35] is the preferred mode of surfactant administration [1]. This is also stated in the United Kingdom national consensus [36]. With this technique, which has a lot of similarities with INSURE, surfactant is administered through a thin catheter which is introduced into the trachea, while maintaining spontaneous breathing and avoiding intubation and MV. More recent randomized controlled trials and meta-analyses suggest that MIST/LISA is superior to INSURE in terms of a composite outcome of death or bronchopulmonary dysplasia [37]. However, despite promising results from randomized controlled trials [37,38-41], the treatment failure rate of MIST/LISA remains considerable. Results on failure rate are variable, taking into account more recent literature, ranging from 30 [42] to $47 \%$ [39] (median INSURE failure rate of $33.3 \%$ in this review). Thus far, there is only very few data on predictive factors for MIST/LISA failure. In one study comparing infants who failed versus those who succeeded MIST/ LISA procedure, GA was the only early factor found to be significantly associated with failure in univariate analysis [43]. This observation was confirmed in a more recent retrospective cohort study, where MIST failure increased with decreasing GA. Other predictive factors for MIST failure were an elevated CRP value, absence of antenatal steroids, and surfactant dose [42]. Most likely, the early risk factors identified in our systematic review for INSURE failure can be considered as possible predictors of MIST/LISA failure as well, although this needs to be confirmed in future studies.

\section{Strengths and Limitations}

A comprehensive search was performed, in the large databases and in additional sources, thereby minimizing the risk of publication bias. All steps of the review process were performed by 2 reviewers independently. We evaluated all potential predictive factors without limitations and thus were able to present a complete overview of the clinical predictors for INSURE failure that have been studied.

Our review has several limitations. First, we had to exclude one possibly eligible study because of translation issues [13]. Second, the quality of studies differed substantially, with only half of the studies providing a multivariate analysis. And third, there was significant methodological heterogeneity between studies. As expected, inclusion criteria for GA and BW, the criteria for INSURE, the procedure itself, and outcome definitions varied across studies. There was also considerable heterogeneity between studies regarding indices for RDS 
severity, classification of these predictors, and cutoff values per index. As a result, we could not conduct a metaanalysis.

\section{Implications for Practice}

Currently available evidence does not provide us with clear-cut decision tools that allow us to select preterm infants with RDS in the first hour of life either for surfactant administration via INSURE or for intubation and continued MV. The results are inconsistent, partly related to heterogeneity across studies, and therefore difficult to apply in clinical practice.

There is some evidence that an extremely low BW (< 750-1,000 g), a lower GA, or more severe RDS lead to a higher risk of INSURE failure. However, based on the results from this systematic review, it was impossible to construct an accurate clinical predictive model.

\section{Implications for Future Research}

There is a need for large and well-conducted cohort studies that evaluate possible early predictive factors for INSURE failure. They should investigate well-defined predictors for RDS, such as early clinical factors or (new) biological markers that can be tested for in the first hours of life. Outcomes should be clearly defined and used in similarly across studies, taking into account multiple confounders using multivariate analysis. In addition, research should be done in a patient population that is representative of the current NICU population (preterms often treated with antenatal steroids and relatively mild RDS). In that way, quantitative synthesis of the size of effect of the individual risk factors becomes possible, more accurate and, thus, applicable for every day clinical practice.

\section{Conclusion}

We presented a complete overview of early predictive factors for INSURE failure. Extremely low BW, low GA, and severe RDS appear to be important risk factors for INSURE failure. However, evidence is inconsistent due to important methodological heterogeneity across studies. Therefore, clinical applicability of these results is limited at the moment and implies the need for future large cohort studies on this subject.

\section{Statement of Ethics}

The authors have no ethical conflicts to disclose.

\section{Disclosure Statement}

The authors have no financial or conflicts of interest to declare.

\section{Funding Sources}

No external funding was received for this paper.

\section{Author Contributions}

All authors contributed substantially to the conceptualization and design of this systematic review. B.D.B.: drafted the initial manuscript. F.D. and F.C.: reviewed and edited the manuscript. All authors approved the final manuscript as submitted and agree to be accountable for all aspects of the work.

\section{References}

1 Sweet DG, Carnielli V, Greisen G, Hallman M, Ozek E, Te Pas A, et al. European Consensus Guidelines on the Management of Respiratory Distress Syndrome - 2019 Update. Neonatology. 2019;115(4):432-50.

2 Sandri F, Plavka R, Ancora G, Simeoni U, Stranak Z, Martinelli S, et al.; CURPAP Study Group. Prophylactic or early selective surfactant combined with nCPAP in very preterm infants. Pediatrics. 2010 Jun; 125(6):e1402-9.

3 Dunn MS, Kaempf J, de Klerk A, de Klerk R, Reilly M, Howard D, et al.; Vermont Oxford Network DRM Study Group. Randomized trial comparing 3 approaches to the initial respiratory management of preterm neo- nates. Pediatrics. 2011 Nov;128(5):e106976.

4 Rojas-Reyes MX, Morley CJ, Soll R. Prophylactic versus selective use of surfactant in preventing morbidity and mortality in preterm infants. Cochrane Database Syst Rev. 2012 Mar;3(3):CD000510.

5 Isayama T, Chai-Adisaksopha $\mathrm{C}, \mathrm{McD}$ onald SD. Noninvasive ventilation with vs without early surfactant to prevent chronic lung disease in preterm infants: a systematic review and meta-analysis. JAMA Pediatr. 2015 Aug; 169(8):731-9.

6 Verder H, Robertson B, Greisen G, Ebbesen F, Albertsen P, Lundstrøm K, et al.; DanishSwedish Multicenter Study Group. Surfactant therapy and nasal continuous positive airway pressure for newborns with respiratory distress syndrome. N Engl J Med. 1994 Oct; 331(16):1051-5.

7 Stevens TP, Harrington EW, Blennow M, Soll RF. Early surfactant administration with brief ventilation vs. selective surfactant and continued mechanical ventilation for preterm infants with or at risk for respiratory distress syndrome. Cochrane Database Syst Rev. 2007 Oct;4(4):CD003063.

8 Perlman JM, McMenamin JB, Volpe JJ. Fluctuating cerebral blood-flow velocity in respiratory-distress syndrome. Relation to the development of intraventricular hemorrhage. $\mathrm{N}$ Engl J Med. 1983 Jul;309(4):204-9. 
9 De Bisschop B, Derriks F, Cools F. Early predictive factors for INSURE failure in the management of preterm infants with neonatal respiratory distress syndrome: a systematic review (and meta-analysis). CRD42015025138. PROSPERO: International prospective register of systematic reviews [Internet]York: National Institute for Health Research; 2015. [cited 2019 Mar 26], Available from https://www. crd.york.ac.uk/PROSPERO/display_record. php?RecordID $=25138$

10 SIGN.ac.uk. Critical appraisal notes and checklists [Internet]. Edinburgh: Scottish Intercollegiate Guidelines Network; 2001 [updated 2015 Sep 07 (randomised controlled trials) and 2013 Feb 04 (cohort studies); cited 2019 Jan 19]. Available from: http://sign. ac.uk/checklists-and-notes.html.

11 Moher D, Liberati A, Tetzlaff J, Altman DG PRISMA Group. Preferred reporting items for systematic reviews and meta-analyses: the PRISMA statement. BMJ. 2009 Jul;339 jul21 1:b2535.

12 Liberati A, Altman DG, Tetzlaff J, Mulrow C, Gøtzsche PC, Ioannidis JP, et al. The PRISMA statement for reporting systematic reviews and meta-analyses of studies that evaluate healthcare interventions: explanation and elaboration. BMJ. 2009 Jul;339:b2700.

13 Afjeh SA, Sabzehei MK. The INSURE method in VLBW preterm infant with RDS. Pajoohande. 2010;15:199-203.

14 Ancora G, Maranella E, Grandi S, Pierantoni L, Guglielmi M, Faldella G. Role of bilevel positive airway pressure in the management of preterm newborns who have received surfactant. Acta Paediatr. 2010 Dec;99(12): 1807-11.

15 Azzabi O, Selmi I, Bellali H, Siala N, Dridi Y, Fetni I, et al. Intubation-Surfactant-Extubation Strategy in a Medical Resource-limited Department: A Prospective Study. J Trop Pediatr. 2016 Apr;62(2):169-70.

16 Brix N, Sellmer A, Jensen MS, Pedersen LV, Henriksen TB. Predictors for an unsuccessful INtubation-SURfactant-Extubation procedure: a cohort study. BMC Pediatr. 2014 Jun; 14(1):155.

17 Cherif A, Hachani C, Khrouf N. Risk factors of the failure of surfactant treatment by transient intubation during nasal continuous positive airway pressure in preterm infants. Am J Perinatol. 2008 Nov;25(10):647-52.

18 Danaei N, Seddigh M, Ghorbani R, Nooripour S. Effective factors of INSURE method failure in treatment of respiratory distress syndrome in preterm infants. Int J Pediatr. 2017;5:6069-76.

19 Dani C, Corsini I, Bertini G, Fontanelli G, Pratesi S, Rubaltelli FF. The INSURE method in preterm infants of less than 30 weeks' gestation. J Matern Fetal Neonatal Med. 2010 Sep; 23(9):1024-9.
20 Gharehbaghi MM, Peirofivar A, Ghojazadeh M. Risk factors contributing to the failure of surfactant administration with INSURE method. J Pioneer Med Sci. 2014;4:55-9.

21 Li T, Jiang H, Liu DY, Li XH. [Risk factors for the failure of the InSure method in very preterm infants with respiratory distress syndrome]. Zhongguo Dang Dai Er Ke Za Zhi. 2014 Jun;16(6):610-3.

22 Morales-Barquet D, Ortega-Vargas AJ, LaraCanul J, Arreola-Ramirez G, Fernandez-Carrocera LA. Risk factors associated to failure of the intubation-surfactant-extubation procedure in preterm infants $1500 \mathrm{~g}$. Perinatol Reprod Hum. 2017 Sep;31(3):124-30.

23 Najafian B, Saburi A, Fakhraei SH, Afjeh A, Eghbal F, Noroozian R. Predicting factors of INSURE failure in low birth-weight neonates with RDS: A logistic regression model. Iran J Neonatol. 2015;5(4):30-4.

24 Naseh A, Yekta BG. INSURE method (INtubation-SURfactant-Extubation) in early and late premature neonates with respiratory distress: factors affecting the outcome and survival rate. Turk J Pediatr. 2014 May-Jun 56(3):232-7.

25 Ognean ML, Stoicescu SM, Boantă O, Năstase L, Gliga C, Cucerea M. Intubation-Surfactant: extubation on continuous positive pressure ventilation. Who are the best candidates? J Crit Care Med (Targu Mures). 2016 May;2(2): 73-9.

26 Tagare A, Kadam S, Vaidya U, Pandit A. Outcome of intubate surfactant rapidly extubate (InSuRE): an Indian experience. Indian J Pediatr. 2014 Jan;81(1):20-3.

27 Talosi G, Mader K, Tajti Z. PO-0765. Introduction of INSURE Therapy - Experiences and limitations. Arch Dis Child. 2014;99 Suppl 2:A505-6.

28 Tooley J, Dyke M. Randomized study of nasal continuous positive airway pressure in the preterm infant with respiratory distress syndrome. Acta Paediatr. 2003 Oct;92(10):11704.

29 Kero PO, Mäkinen EO. Comparison between clinical and radiological classification of infants with the respiratory distress syndrome (RDS). Eur J Pediatr. 1979 Apr;130(4):271-8.

30 Horbar JD. A calculator program for determining indices of neonatal respiratory distress syndrome severity. Am J Perinatol. 1987 Jan;4(1):20-3.

31 Subhedar NV, Tan AT, Sweeney EM, Shaw NJ. A comparison of indices of respiratory failure in ventilated preterm infants. Arch Dis Child Fetal Neonatal Ed. 2000 Sep;83(2):F97100 .

32 Srisuparp P, Marks JD, Khoshnood B, Schreiber MD. Predictive power of initial severity of pulmonary disease for subsequent development of bronchopulmonary dysplasia. Biol Neonate. 2003;84(1):31-6.
33 Dimitriou G, Fouzas S, Giannakopoulos I, Papadopoulos VG, Decavalas G, Mantagos S. Prediction of respiratory failure in late-preterm infants with respiratory distress at birth. Eur J Pediatr. 2011 Jan;170(1):45-50.

34 Dargaville PA, Aiyappan A, De Paoli AG, Kuschel CA, Kamlin CO, Carlin JB, et al. Minimally-invasive surfactant therapy in preterm infants on continuous positive airway pressure. Arch Dis Child Fetal Neonatal Ed. 2013 Mar;98(2):F122-6.

35 Göpel W, Kribs A, Härtel C, Avenarius S, Teig N, Groneck P, et al.; German Neonatal Network (GNN). Less invasive surfactant administration is associated with improved pulmonary outcomes in spontaneously breathing preterm infants. Acta Paediatr. 2015 Mar; 104(3):241-6.

36 Banerjee S, Fernandez R, Fox GF, Goss KC, Mactier H, Reynolds P, et al. Surfactant replacement therapy for respiratory distress syndrome in preterm infants: united Kingdom national consensus. Pediatr Res. 2019 Jul;86(1):12-4. ; Epub ahead of print.

37 Isayama T, Iwami H, McDonald S, Beyene J. Association of noninvasive ventilation strategies with mortality and bronchopulmonary dysplasia among preterm infants: a systematic review and meta-analysis. JAMA. 2016 Aug;316(6):611-24.

38 Kanmaz HG, Erdeve O, Canpolat FE, Mutlu B, Dilmen U. Surfactant administration via thin catheter during spontaneous breathing: randomized controlled trial. Pediatrics. 2013 Feb;131(2):e502-9.

39 Kribs A, Roll C, Göpel W, Wieg C, Groneck P, Laux R, et al.; NINSAPP Trial Investigators. Nonintubated surfactant application vs conventional therapy in extremely preterm infants: a randomized clinical trial. JAMA Pediatr. 2015 Aug;169(8):723-30.

40 Rigo V, Lefebvre C, Broux I. Surfactant instillation in spontaneously breathing preterm infants: a systematic review and meta-analysis. Eur J Pediatr. 2016 Dec;175(12):1933-42.

41 Aldana-Aguirre JC, Pinto M, Featherstone RM, Kumar M. Less invasive surfactant administration versus intubation for surfactant delivery in preterm infants with respiratory distress syndrome: a systematic review and meta-analysis. Arch Dis Child Fetal Neonatal Ed. 2017 Jan;102(1):F17-23.

42 Janssen LC, Van Der Spil J, van Kaam AH, Dieleman JP, Andriessen P, Onland W, et al. Minimally invasive surfactant therapy failure: risk factors and outcome. Arch Dis Child Fetal Neonatal Ed. 2019, Epub ahead of print.

43 Ramos-Navarro C, Sánchez-Luna M, Zeballos-Sarrato S, González-Pacheco N. Less invasive beractant administration in preterm infants: a pilot study. Clinics (São Paulo). 2016 Mar;71(3):128-34 